\title{
SEARCHING FOR SUCCESS FACTORS OF AGRITOURISM: THE CASE OF KLEVE COUNTY (GERMANY)
}

Mirjam Bosmann ${ }^{1}$, Gert-Jan Hospers², Dirk Reiser ${ }^{3}$

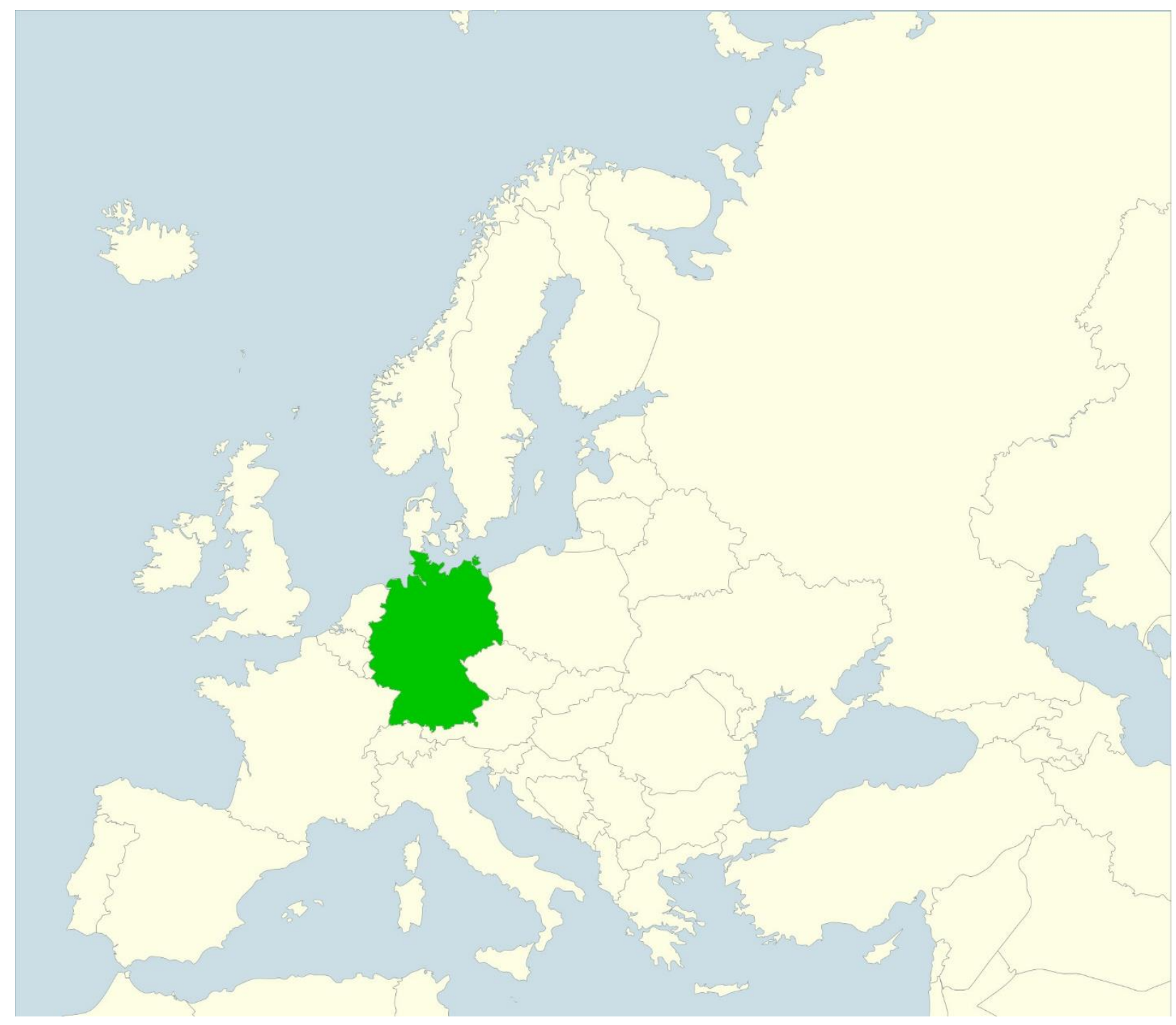

\footnotetext{
${ }^{1}$ Mirjam Bosmann, Rhine-Waal University of Applied Sciences Kleve, Germany and Radboud University Nijmegen, the Netherlands; e-mail: mirjam.bosmann@hsrw.org

${ }^{2}$ Gert-Jan Hospers, Radboud University Nijmegen, the Netherlands; email: g.hospers@fm.ru.nl

${ }^{3}$ Dirk Reiser, Rhine-Waal University of Applied Sciences Kleve, Germany; email: dirk.reiser@hochschule-rheinwaal.de
} 
Abstract: Agritourism is increasing in popularity as more urban residents appreciate the slower paced rural environment and its authenticity. External influences (political crises and pandemics) have recently reduced mobility which makes agritourism an attractive alternative to former more distant holiday destinations. Agritourists are interested in working farms, local production and animal husbandry. Some European regions (e.g., Bavaria and South Tyrol) have successfully developed agritourism whereas the majority of rural regions are left behind. Agritourism diversifies farmers' business model and increases their income. For our study, we chose Kleve County (Lower Rhine Area, Germany) as an exemplary region for a touristically unknown rural area. Regional opinion leaders, farmers and industry experts were interviewed to share their experiences about factors that could further and contribute to successful development of agritourism. The results of our case study and supplementary market interviews suggest that its success in less known rural regions depends on the geographic location, mutual efforts of local visionary entrepreneurs, regional beneficial networks and on committed political stakeholders to develop a sustainable business model. The results may be useful for other comparable European rural regions to diversify their farming and develop their own business model.

Key Words: diversifying income, agritourism, rural development, success factors, networks in agritourism, political influence, Germany

Zusammenfassung: Agrotourismus wird immer beliebter, da immer mehr Stadtbewohner die langsamere, ländliche Umgebung und deren Authentizität schätzen. Äußere Einflüsse (politische Krisen und Pandemien) haben in letzter Zeit die Mobilität reduziert, was den Agrotourismus zu einer attraktiven Alternative zu früheren, weiter entfernten Urlaubszielen macht. Agrotouristen interessieren sich für arbeitende Bauernhöfe, lokale Produktion und Tierhaltung. Einige europäische Regionen (z.B. Bayern und Südtirol) haben den Agrotourismus erfolgreich entwickelt, während die Mehrheit der ländlichen Regionen ins Hintertreffen geraten ist. Agrotourismus diversifiziert das Geschäftsmodell der Landwirte und erhöht ihr Einkommen. Für unsere Studie wählten wir den Kreis Kleve (Niederrhein, Deutschland) als Beispielregion für einen touristisch unbekannten ländlichen Raum. Regionale Meinungsführer, Landwirte und Branchenexperten wurden interviewt, um ihre Erfahrungen über Faktoren zu teilen, die eine erfolgreiche Entwicklung des Agrotourismus fördern und unterstützen können. Die Ergebnisse unserer Fallstudie und der ergänzenden Marktinterviews deuten darauf hin, dass der Erfolg in weniger bekannten ländlichen Regionen von der geographischen Lage, den gemeinsamen Anstrengungen lokaler visionärer Unternehmer, regionaler nützlicher Netzwerke und von engagierten politischen Akteuren abhängt, um ein nachhaltiges Geschäftsmodell zu entwickeln. Die Ergebnisse können für andere vergleichbare europäische ländliche Regionen nützlich sein, um ihre Landwirtschaft zu diversifizieren und ihr eigenes Geschäftsmodell zu entwickeln.

Schlüsselwörter: Einkommen Diversifizierung, Agrotourismus, Entwicklung ländlicher Regionen, Erfolgsfaktoren, Netzwerke im Agrotourismus, politischer Einfluss, Deutschland

\section{Highlights:}

- Popular rural regions have successfully diversified their source of income through the development of agritourism.

- We have identified factors which influence the development of agritourism in touristically underdeveloped rural regions. 
- Proximity to urban centers plays a significant role for attracting visitors from nearby.

- Political decisions to prepare and support the playing level field to provide optimal conditions for motivated entrepreneurs to succeed.

- Agritourism networks offer and bundle activities to strengthen rural development.

\section{Rural regions and the successful development of agritourism}

Since the 1980s, many European countries have seen a rise in domestic agritourism (Barbieri, 2019). Mainly city-dwellers are looking for leisure and recreational activities in nearby rural areas to escape the hustle and bustle of their daily living environment. Tourists either stay for a day, for weekends or for short holidays. In line with current trends of sustainability, they are looking for a 'time-out' to experience 'authentic' leisure activities, on farms, in the countryside and in nature (Barbieri, 2019; Weisskopf, 2018). Travel statistics show that while tourism generally is on the rise, the individual length of stays decreases. In 2017, half of all reported trips in Europe were short and domestic (eurostat, 2019). This behavioral pattern is influenced in Germany by lifestyle changes, increasing mobility and changes in working and leisure time behavior (WTTC, 2019).

Aside from pre-existing trends in lifestyle and political issues, the current pandemic stirs an increasing interest in domestic holidays. Many foreign countries are in unpredictable and changing lockdowns, due to the ongoing global Covid-19 pandemic. Consequently, in 2020, the United World Tourism Organization (UNWTO) noted the biggest decline in tourism ever recorded, with a worldwide decrease by $60-80 \%$ (UNWTO, 2020). Health considerations represent the foremost reason why tourists prefer domestic holidays (Hirsch, 2020). It remains uncertain whether this reflects only a current and transient trend or an emerging change in general touristic behavior which may persist after the waning of the pandemic. Regional tourism offers the opportunity to keep the travel radius small and support the local economy.

In Europe, agritourism began to develop in Italy and was formally recognized by Italian legislation in 1985, which was accompanied by regional law (Porcaro, 2009). The Italian agritourism business has developed from its beginnings into an economic success story and encouraged other countries to follow. Italian farmers benefit from agritourism. They profit from financial support, public marketing, networking activities and committed politicians. The diversity of network activities enriches the regional value of touristic experiences (Santucci, 2013).

In 1997, the Council of the European Union followed the successful Italian example. The European Union and its member states began to subsidize interregional projects (EU project Interreg, the NRW project "Ländlicher Raum" (countryside)) (NRW, 2017) to maintain ecosystems, stimulate rural economy and create new regional business opportunities. These measures were intended to help farmers to compensate for decreasing agricultural revenues by opening their farms to agritourists. They support local businesses and contribute to the preservation of the rural landscape (Landdata, 2020). A Dutch study confirms observations made in the course of Italian agritourism development. Economic diversification generally increases incomes of rural regions by preserving the environment and food production (Meraner, Heijman, Kuhlman, \& Finger, 2015).

With increasing demand for agritourism and its growing economic importance one must ask "what is agritourism and how can it be defined"?

The term agritourism can be generally considered a subcategory of rural tourism (Mahaliyanaarachchi, 2015). McGehee and others have defined the essential elements as a combination of active agriculture combined with tourism (McGehee, 2007). This broad definition cannot be contradicted, but it lacks details. Hall and Page find it difficult to define agritourism as the literature attributes different labels and definitions to agritourism based on a variety of different characteristics and setups leading to a blurred picture (Hall \& Page, 2006). "What is agritourism and what it is not" lacks a holistic definition and remains a debated and not fully resolved academic question (Philip, Hunter, \& Blackstock, 2010). Most published studies have discussed the supplier and not the customer side of agritourism (Stotten, Maurer, Herrmann, \& Schermer, 2019). Different labels and definitions were summarized by Philip et al. (2010). They proposed and 
established a framework of three key elements for genuine agritourism. These essential elements include activities on working farms (WF), non-working farms (NWF) and authentic agricultural activities (Philip et al., 2010). In a follow-up paper by the same authors, Flanigan et al. (former name Philip) (2014) the" typology of agritourism" was extended by taking the relevance of a working/non-working farm into consideration by analyzing the level of contact with agriculture (Flanigan, Blackstock, \& Hunter, 2014).

Staying on a farm enables contacts with hosting families who provide an opportunity to participate in farm life, learn about regional food and rural environment (Barbieri \& Mshenga, 2008; Flanigan et al., 2014; Philip et al., 2010; Streifeneder, 2016). These activities lead to personal experiences that can be memorized and recalled (Cohen, 1988; Di Domenico \& Miller, 2012; Streifeneder, 2016; Zatori, Smith, \& Puczko, 2018). Memorable experiences are keys to successful agritourism (Cohen, 1979; Pine \& Gilmore, 1998; Zatori et al., 2018). They are strongly related to the authenticity of holiday images (MacCannell, 1973; Rickly, 2018) and contribute to their perceived value. Authenticity is positively correlated with perceived quality as was shown by an online evaluation of typical local restaurants which may serve as a respective surrogate marker (Kovacs, Carroll, \& Lehman, 2014).

Tourists especially value their vacation when it exceeds prior expectations (Del Bosque, San Martín, Collado, Del Salmones, \& Del Mar, 2009). Positive images, stories, memories and emotions lead to the perception of successful holidays (Morgan, Pritchard, \& Piggott, 2003). The uniqueness of different destinations, their perceived images and their authenticity also play an important role for agritourists in making their holiday choices (Croes \& Semrad, 2018; Karampela \& Kizos, 2018; Pine \& Gilmore, 2000; Zatori et al., 2018). Landscape, climate, weather conditions, local products (potatoes, grain, dairy products, apples and grapes) and the ways in which they are cultivated create a unique rural identity (Karampela \& Kizos, 2018). These attributes are important factors in touristic competitiveness and success (Croes \& Semrad, 2018).

Farms and regions contribute to the development of destination images (Cohen-Hattab \& Kerber, 2004; Cohen, 1988; Govers, 2007). A strong holiday destination image increases regional popularity and supports branding (Cohen, 1988; Cohen-Hattab \& Kerber, 2004; Echtner \& Ritchie, 2003; Govers, 2007). Many European rural regions like Bavaria, Tuscany and Tyrol have successfully diversified into agritourism. Small and medium-sized farms offer room and board and provide authentic agritourism experiences. They are mostly run by families where men usually do the farming and women the hosting (McGehee, Kim, \& Jennings, 2007; Savage, Barbieri, Jakes, $\&$ Morais, 2018). They are flexible in responding to various customer demands (Brunner-Sperdin \& Peters, 2009; Philip et al., 2010)

Farms and regions must be recognisable and attractive through their distinct rural attributes which can be agriculture, viticulture, cheese production, horse breeding and rural events (e.g., grape harvest, grain harvest, Christmas and Food markets). Typical rural features must be made public and can be transmitted via print media, online platforms, by bloggers and by personal communication. They support brand development, brand associations, brand salience and customer loyalty (Konecnik \& Gartner, 2007; Pike, 2007).

Agritourism fits well into the current trend of sustainable lifestyles (Weisskopf, 2018). It includes activities like self-harvesting, hunting, fishing, wildlife observations and visits to rural amusement parks providing leisure and recreation (Barbieri, Mahoney, \& Butler, 2008; Flanigan et al., 2014). Besides cultural attractions, traditional lifestyle experiences and craft production may also contribute to a better understanding of farming and farming products (Sinabell, 2001). Witnessing food production is an educational experience for all age and socioeconomic groups (LaPan \& Barbieri, 2013). Agritourists are usually curious and educated customers (Cela, KnowlesLankford \& Lankford, 2007). They seem to be more interested in sustainable holidays (Sidali, Huber, \& Schamel, 2017) whereby the geographic location is crucial for their choice (Karampela \& Kizos, 2018).

Rural regions gain economic benefits from agritourism. Usually, this type contributes to their development (Xue, Kerstetter, \& Hunt, 2017). Rural regions are characterized by a regional identity that has traditionally been determined by its geographic, economic and political factors. Examples of popular European tourist regions are South Tyrol in northern Italy, Tyrol in Austria, 
Bavaria in south-east Germany and the Black Forest in south-west Germany. These regions possess strong and well-developed agritourism sectors (Barbieri, Sotomayor, \& Aguilar, 2017) connected with a traditional regional identity. South Tyrol and Bavaria offer general and rural consistent hospitality and local cuisine. Both regions have a beautiful mountain range, hiking trails and so-called 'Gemütlichkeit' (coziness) that have become part of their regional identity. The Black Forest offers similar advantages, hiking trails, typical crafts (the famous cuckoo clock), historical architecture and a beautiful mountainous landscape next to the French border including the mild climate of the Upper Rhine Plain. Each region stands for its unique and profit-making attractions supplementing farming incomes (Novelli, Schmitz, \& Spencer, 2006). Additionally, a rising awareness of social, cultural and regional aspects have led to an extension of the classic factors by the appreciation of local socioeconomic and cultural values (Paasi, 2003).

Some regional identities are driven by typical products (e.g., the 'Wine Route' in south-west Germany) or experiences (e.g., mountain climbing, cycling, and adventure-park) (Ghali-Zinoubi \& Toukabri, 2019; Pine \& Gilmore, 1998; Zatori et al., 2018). Location seems to play a significant role in tourists' choice making (Bolton \& Drew, 1991; Cronin, Brady, \& Hult, 2000; Karampela \& Kizos, 2018). The proximity to conurbations could be an important determinant for rural development and regional-economic success (Bertacchini, Nuccio, \& Durio, 2019).

\section{Study Concept and Methodology}

Previous studies on agritourism have been conducted in popular touristic regions. Many of them are located in Austria (Embacher, 1994; Sinabell, 2001; Stotten et al., 2019; Streifeneder, 2016). Little is known about the possibilities of development and of success factors of agritourism in less attractive and therefore less popular regions. In 2019, 983,600 agritourists were counted in the German state of North Rhine-Westphalia (statista, 2020) while 17.9 million inhabitants lived in this state (IT.NRW, 2019).

The case study in this paper was conducted in Kleve County in the state of North RhineWestphalia (Fig. 1) which is bordering to the Netherlands in the west. Kleve is not only the name of the county (311,400 inhabitants), but also the name of its main town (51,400 inhabitants). The area is traditionally known for its flat landscape, milk production, horticulture and its castles. This case study will look for success factors supporting the transformation of this less-attractive rural region into a holiday destination for agritourists.

The study follows a modified conceptual framework (Figure 2) that is based on a combination of research models from different fields. It incorporates interviews to relevant topics drawn from strategic hospitality research (Olsen, 2008), tourism geography (Jansen-Verbeke, 2008) and agritourism (Gil Arroyo, Barbieri, \& Rozier-Rich, 2013). The local interview partners were selected from a range of different responsibilities and functions in agritourism businesses. The conceptual framework below (Figure 2) has served as an interview guideline for the exploration of positive and negative factors influencing rural touristic development in the case study region. The generated information reflects personal expert opinions about regional sales, education, hospitality and entertainment.

Attitudes, experiences and beliefs of the interviewed persons (abbreviated in the text as IP) were summarized for each topic. The term 'agritourism' was used in its widest definition as any setting in which agriculture and tourism may take simultaneously place. 


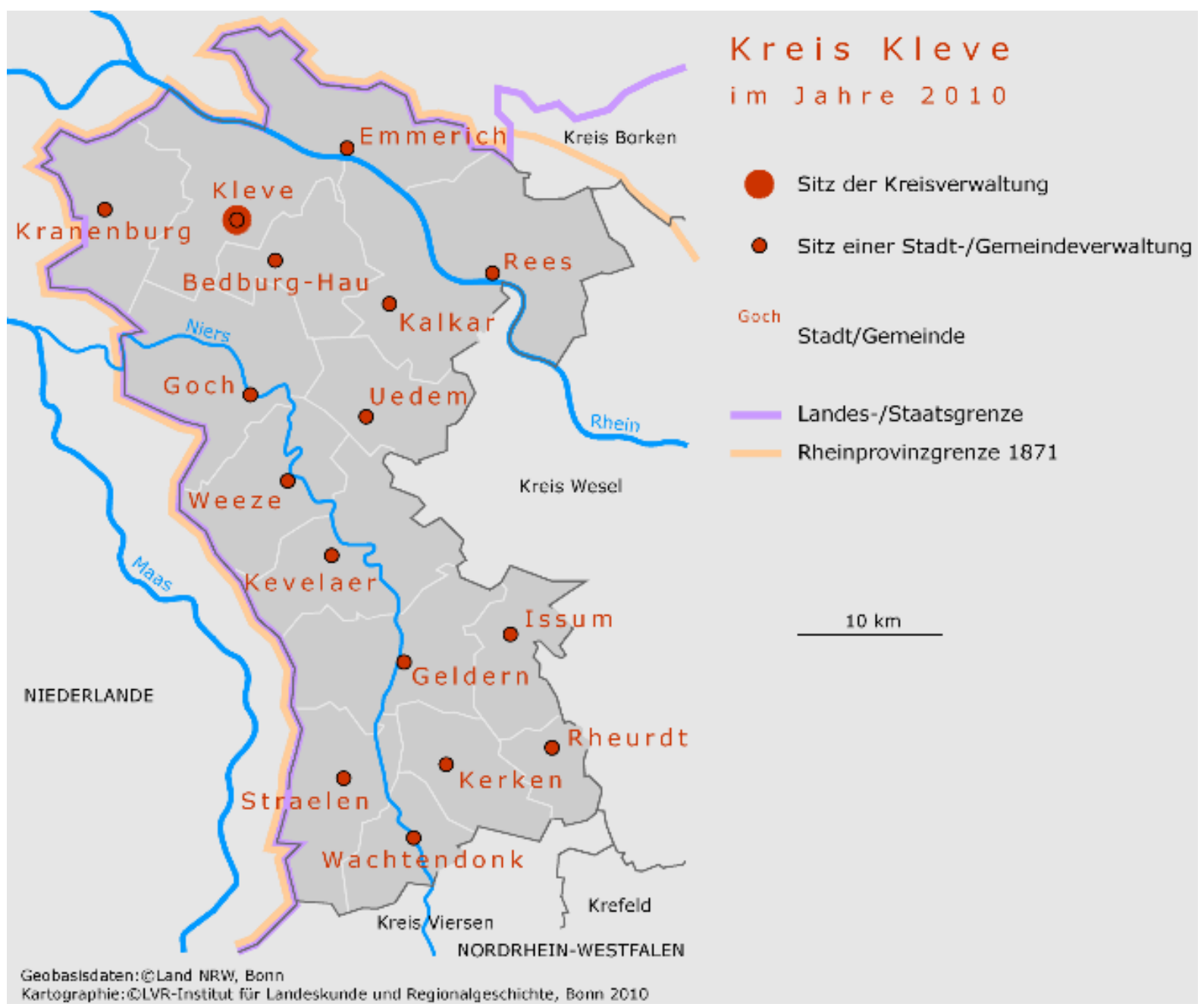

Fig 1. Kleve County (Institut für Landeskunde und Regionalgeschichte (2010).

Interview Expertise

Interview Categories

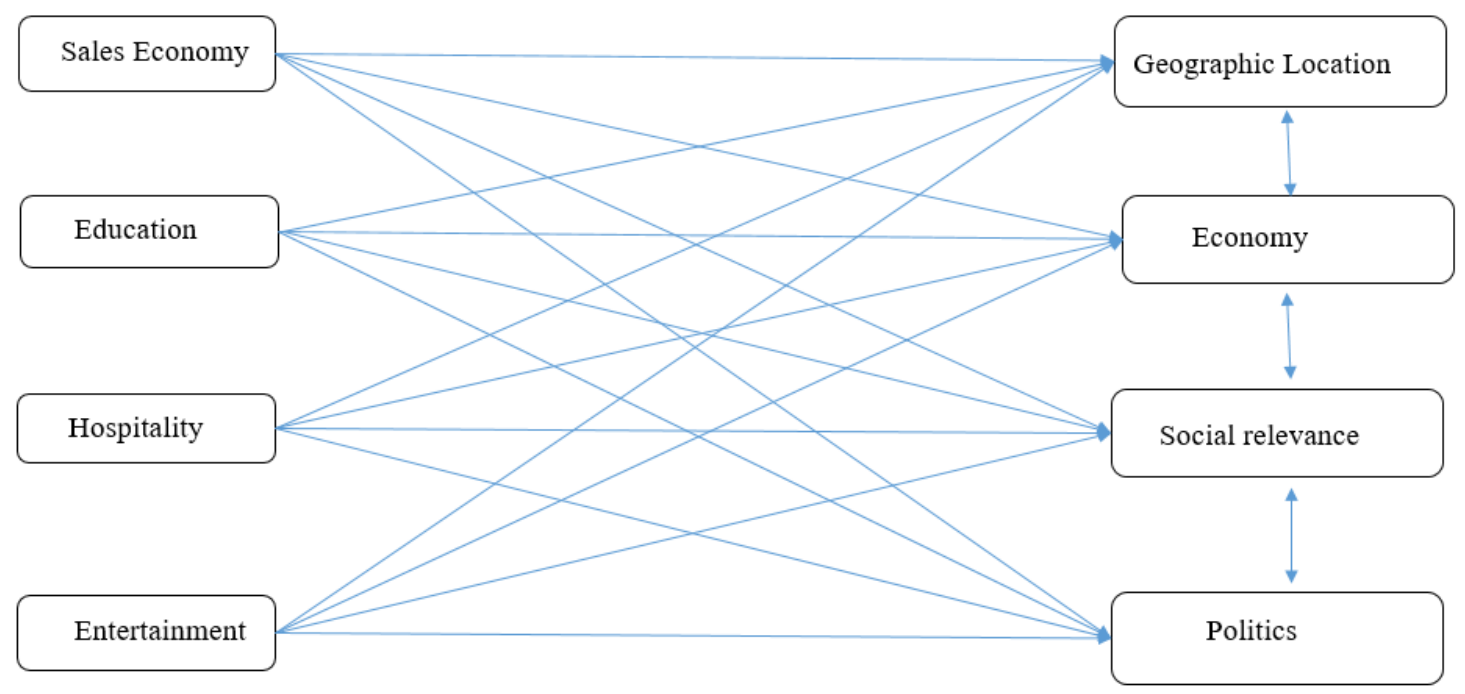

Fig 2. Conceptual framework adapted and modified from Jansen-Verbeke (2008) and Olsen (2008). 
Interview partners were selected according to their general expertise and their special focus on different sectors of agritourism pertaining to sales/economy, education, hospitality and entertainment (Table 1). Experts from private and public sectors were invited for an interview. Eight of 15 agreed to participate, seven either did not answer the invitation or declined their participation for unknown reasons.

Tab 1. Interview partner. Source: researcher's selection of interview partners and research information about interviews

\begin{tabular}{|c|l|l|l|c|}
\hline (IP) & Interview partner & Expertise & Date of interview & $\begin{array}{c}\text { Interview length in } \\
\text { minutes }\end{array}$ \\
\hline 1 & Business development Kleve & Entertainment & Oct 7th, 2019 & 32 \\
\hline 2 & $\begin{array}{l}\text { Representative of an } \\
\text { Interreg Project }\end{array}$ & Education & Oct 9th, 2019 & 47 \\
\hline 3 & Amusement park & Entertainment & Oct 15th, 2019 & 32 \\
\hline 4 & Regional tourism & Hospitality & Oct 16th, 2019 & 55 \\
\hline 5 & Agrobusiness network & Education & Nov 6th, 2019 & 48 \\
\hline 6 & Farm Store/wholesaler & Sales & Nov 12, 2019 & 85 \\
\hline 7 & Agritourism farm & Hospitality & Nov 25th, 2019 & 56 \\
\hline 8 & $\begin{array}{l}\text { Women's agri-network/ } \\
\text { (farmers' wives) }\end{array}$ & Education & Jan 21th, 2020 & 70 \\
\hline & Observation & & & Length of stay in \\
minutes
\end{tabular}

The study participants were exposed to the questions listed in Table 2 in line with the reported conceptual framework categories (Figure 2). The interviews were conducted between October 2019 and January 2020.

Tab 2. Interview questions. Source: own interview questions based on figure 2

General question:

1. How do you estimate the importance of agritourism in Kleve County?

Geographic influence:

2. What is the relevance of accessibility of Kleve County?

3. What role does sustainability or closeness to nature play?

Economic influence:

4. What has been achieved economically?

5. Which projects are still planned to develop agritourism?

6. Has agritourism changed in recent decades?

Social influence:

7. How is agritourism in Kleve County perceived by tourists and population?

8. How is agritourism in "Kleve County" perceived by the population?

Political influence:

9. What role do political decisions play for agritourism? What political obstacles or regulations exist? 
Due to the limited response to interview requests, two additional unstructured background observations and interviews were conducted at two rural events (Christmas market and farmers' market), where exhibitors were asked about the significance of these events. Such agritourism events may represent additional success factors contributing to rural development.

These two markets may give an additional exemplary sample for the image of Kleve County. Both markets have an established regional reputation and attract many visitors from the metropolitan regions located nearby (Rhine-Ruhr area and the Dutch city of Nijmegen).

The first observation was conducted at the traditional Christmas Market at the castle of Moyland in Bedburg-Hau, where mulled wine is served and Christmas bakeries next to handmade crafts are sold. Exhibitors answered questions about their incentives and contributions to the event (IP 9). The Christmas market traditionally opens for a long weekend and presents regional handcrafted goods. Most exhibitors come every year. It is a privilege to receive an exhibition spot and there is a waiting list.

The second observation took place at the farmer's food market 'Haus Riswick' in Kleve city, a farm for agricultural research run by the state of North Rhine-Westphalia. This public farm offers a weekly food market where local farmers sell their products. This farm is regionally known for its open day and Easter Market. Both market interviews were conducted to understand extended business practice of agritourism and the relationship to other regional businesses encompassing farming, culture and traditions.

The scheduled in-depth interviews took place in the offices of the interview partners and were audio recorded with the written permission of all participants. Four of the eight interview partners (estimated age about 50 years) were men, four were women. The average interview lasted 52 minutes (range between 32 minutes - 1 hours 25 minutes). The recording was later transcribed into Word documents, which were coded and analyzed with support of the software tool Atlas.ti. Digital coding ${ }^{4}$ for contents were linked to statements of the interview partners. They established connections for interviewed topics and enabled the stratification, among results and answers given by different participants. The tool also gave insight views of code combinations implying relationships between events or occasions.

\section{Results}

\subsection{Christmas Market at Moyland Castle and Fresh Food Market at Haus Riswick}

The popular Christmas Market at Moyland castle in Bedburg Hau is a regional attraction for typical local products. In 2019, 36,508 tickets were sold despite an entrance fee of $7.50 €$ per person which demonstrates its value and popularity to the guests (Grass, 2019). Interviewed sellers and visitors state that they enjoy the Christmas related atmosphere, especially at night when the castle and the market are illuminated. Local exhibitors sell handcrafted items and offer mulled wine, hot chocolate, and self-made Christmas bakery to locals and visitors from German and Dutch metropolitan centers.

Additional observations and interviews were conducted at 'Haus Riswick', a research-farm run by the State of North Rhine-Westphalia, working on improving different agricultural products (e.g., cereals, vegetables) and animal husbandry. To the general public, the farm is particularly known for its Easter market and its open days each of which attract about 15,000 regional and supraregional visitors per year. Visitors appreciate to experience authentic agriculture. Fresh regional food obtained directly from producers is appreciated by an increasing number of customers (e.g., meat, vegetable and cheese). Both market events draw regional attention and contribute to popularity and identity of the region.

\footnotetext{
${ }^{4}$ Code/coding: method in qualitative research. Defines data.
} 


\subsection{Expert interviews}

\section{Location}

All interview partners shared different responsibilities for agritourism or regional events and were directly and actively involved. They see touristic potential in the geographic location of Kleve County, its active agriculture and the proximity to metropolitan areas. The county is well connected via motorways and can be easily reached from urban centers (e.g., Düsseldorf, Cologne, Nijmegen) in one or two hours. Most tourist come from within a radius of 200 kilometers, mostly from German and Dutch conurbations. This is seen as an important future success factor by all participants (IP 1-8) and is reflected in the following interview statements of the first interview category:

"We are easily accessible, and this applies to tourism as well as to business locations. We are well connected via motorways." (IP 1)

"Compared to parks [rural entertainment parks] in the east [of Germany], for example, we have huge advantages in that we are close to the Ruhr area with about 5 million people, but still live in the country" (IP 3)

"Guests do not drive far to get out and experience nature." (IP 4)

Why should people visit Kleve and Kleve County? The town and the region of Kleve are nationwide rather unknown as one interview partner experienced during her visit to the Agricultural Fair in Berlin (Grüne Woche Berlin - Green week Berlin) (IP 2):

"Even if you say Niederrhein, in most people's minds, I would say it's just flat land and lots of nothing. I don't believe that there is a concrete idea of the Lower Rhine and that it really has to be built up first and established in people's minds." (IP 2)

With an intensifying lifestyle, more people like to 'flee' from the stress of big cities and conurbations to experience rural life for leisure and recreation (IP1). This is why all experts agree that agritourism constitutes a growing niche in the tourism industry (IP 1-8). Kleve County is known for its agriculture and horticulture providing regional food and flowers. It is less known for a wide offer of leisure activities, hiking, horseback riding, fishing, canoeing and cycling. Neighboring the Netherlands bicycle lanes are integrated into a well-organized knot-based Dutch cross-border bicycle-route system (IP 1, 4) facilitating to explore the region and its scenery. Kleve County is also home to historic city centers and castles which offer numerous cultural programs (IP 4; Observation 9). Some entertainment events attract huge crowds like the Haldern-Rees ('Haldern Punkrock Festival'), the Weeze Festival ('Parookaville Electronic Music Festival') and the Easter and Christmas Markets organized in the county's towns and villages. Historic sites and cultural events increase regional awareness and give indirect support for the development of agritourism.

\section{Economy}

In the last decade, local tourism networks and agricultural businesses have begun to realize the value of agritourism networks providing cultural, recreational and economic value (IP 1-2) during the main tourist season between March and the end of October. Christmas markets and wellness weekends have extended the season into December, providing additional income to the regional tourism industry (IP4). However, to increase the attractiveness for visitors, the quality ratings of available accommodations play a significant role (IP 7):

"The topic of agritourism has only been coming up here for the last five or six years, when the development of services, for example, in Straelen, began in cooperation between the municipality on the one hand and local colleagues in tourism and horticultural businesses on the other. ${ }^{5 "}$ (IP 1)

In the past twenty years, overnight stays in Kleve County have more than tripled and almost reached one million stays in 2018, providing substantial additional revenue (IP 1). Agritourists

\footnotetext{
${ }^{5}$ Straelen is a town and municipality in Kleve County.
} 
come for daytrips, for short holidays or longer weekends (IP 1). Accommodation facilities in hotels, holiday-apartments, comfortable beds and delicious local meals increase pleasure and add to the holiday experience (IP 4). The county provides 400 holiday apartments ${ }^{6}$ (IP 4). Additional accommodations are offered on farms and on camping sites. Nature, the typical Lower Rhine landscape, agriculture and horticulture are great attractions for city-dwellers (IP 2). Local tourism services inform about activities, attractions and accommodations on the websites www.klevetourismus.de and www.niederrhein-tourismus.de (IP 4). Agritourism bookings can also be carried out online via the website www.bauernhofurlaub.de (IP 7) or directly at the farm.

All experts agree that agritourists are an active group looking for regional authentic experiences (IP 2, 3, 4, 6, 7, 8). Many visitors bring their bikes and use them for outdoor activities and local sightseeing trips (IP 2). The county offers scenic bicycles routes ('Milchradweg' and 'Agrifun'7), which also connect to farms along the way (IP 2,3). Some farms have opened up their own stores where tourists can buy local and fresh seasonal agricultural products at a fair price (e.g., strawberries, asparagus, potatoes, cabbage). Other farm owners have successfully changed their business model from traditional farming to an agritourism enterprise providing entertainment and education for children and adults about food production and animal husbandry (IP 3, IP 7). The interviews show that the interest of agritourists diverge into different pathways. Some visitors are interested in working farm experiences and want to participate in farming activities, while others prefer educational non-working farm experiences (e.g., bicycle tours 'farm to farm', events on farms that inform about agriculture and animal husbandry) and rural entertainment in amusement parks (teaching children about country life). These activities can be combined with culinary delights in typical local restaurants (IP 4).

Successful development of agritourism needs political commitment, entrepreneurial vision, including private and public marketing. This is illustrated by some interview statements, which show how new and seemingly unusual ideas can successfully be transformed into a flourishing agricultural business and rural attraction for families and children:

"We started with a corn labyrinth about 20 years ago...and have been adding attractions since then." (IP 3)

"....today, my son is doing farming and I am doing agritourism." (IP 7)

It can be concluded that farms and farm-related activities enhance rural experiences and create loyal visitors and customers for regional farm products.

"...people will have families and children. And then they give their children organic carrots, from us." (IP 6)

"...people come to us because they get products in quality and freshness and volume, which they may not get elsewhere." (IP 6)

In combination with rural experiences, Kleve County offers a wide variety of other activities which attract additional tourist segments. Some families come for horseback riding as there are many riding stables to choose from (IP 6). Other families visit the rural entertainment park, where children learn about agriculture and animal husbandry (IP 3). Another group of tourists combines cycling with an overnight stay to visit a museum or some other places of interest the next day. Activities on waterways, like boating on the Rhine arms and Niers, or the Maas on the Dutch side, are (agri-) tourist attractions. Places of interest in the region are the museums in Kleve, historic inner cities (e.g., Kalkar) and castles (Moyland Castle, Walbeck Castle). Wild geese, storks and cranes are worth seeing at the end of summer (IP1; IP2). Consumer demand for combining agriculture and tourism is increasing but - except for a few pioneering entrepreneurs - this opportunity has not been sufficiently exploited and developed yet. An increase of tourist numbers should boost the economy and create new local job opportunities (IP 3).

\footnotetext{
${ }^{6}$ Only apartments with 9 beds or more are statistically relevant.

${ }^{7}$ Agrifun is a cross-border project which is supported by the European Union. Local tourists equally benefit from this project by strengthening not only cross-border relationships but also by learning about food cultivation (Agrifun, Milchradweg) (IP 2).
} 


\section{Social acceptance}

Interest and demand for agritourism is rising. Families with children and classes of students visit farms for educational and recreational purposes. They are looking for personal contact with the farming family which is important for an authentic and memorable farm experience (IP 7) (Zatori et al., 2018):

"Actually, the farm is first represented by the farmer, his personality and the farmer's wife. That was the heart of it all [agritourism]. It is actually important [for farmers] that you stay in contact with the guests." (IP 7)

Farmers enjoy high acceptance (IP 3 ) and the numbers of overnight stays point to increasing popularity (IP 1, 4). Kleve County claims to possess a welcoming atmosphere which contributes to the wellbeing of guests in the city and on the countryside (IP 1). Employing locals in agritourism strengthens the bonds between locals and tourists (IP 3). Local friendliness enhances the holiday experiences and makes guests return. This secures local jobs and income (IP $\mathbf{3}$ ) as is stated by the owner of a rural amusement park.

Agritourists are taught about regional food which they can self-harvest. The interviewed owner of a farm store states that an increasing number of customers are attracted to regional food. Today, the farm store's main customer segment is well-educated. Through continuous advertising the store owner hopes to reach more socioeconomic layers of customers. He sees potential for a growing sustainable food market and is increasing his own production sites (IP 6) as evolving organic agriculture, environmental, social and economic sustainability are gaining more importance (IP 5).

To increase the attractiveness of agritourism, affordable pricing is important to make holidays available to families with children (IP 3). The economic future of successful agritourism seems to lie in beneficial co-operation and developing networks. Organization and projects like 'Landfrauen' and 'Agrifun' support agritourism development (IP 2). Recent activities like the street painter competition in Geldern, the music festivals Haldern-Pop (Rees-Haldern) and the Parookaville Festival at Weeze Airport are not directly related to agritourism, but may increase nationwide awareness of the Lower Rhine Area and attract additional visitors (IP 4).

One interview partner adds:

"I believe that there is still a long way to go in order to make the Lower Rhine really known ..., but agritourism will definitely find its place." (IP 2)

\section{Political support}

The expert interviews revealed that political support plays a major role as a success factor in the development of agritourism. Public service providers like 'Niederrhein Tourismus' (IP 4) contribute to regional marketing in print and in electronic media (Blog 'Niederrhein aktuell') (IP 4). Sustainable farming has also become a relevant political issue (IP 3) and will give farmers a chance to correct their public image by improving knowledge and understanding of agriculture (IP 2). Large regional marketing projects were successfully initiated by the 'Landfrauen' (e.g., Easter Market and open day at the farm Riswick in Kleve). Other smaller projects for regional food markets were less successful (IP 8). The traditional 'Landfrauen'- network represents the backbone of agritourism in Kleve County. No other agricultural network is as well connected as this one. Missing recognition and insufficient appreciation of the 'Landfrauen'-network are however leading to less participation of young farming women. Some chapters had to close as fewer younger farming ladies are willing to join the network (IP 8). This might result in a negative impact on regional agritourism development.

One interview partner did not see a link between agritourism and regional political development claiming that the marketing of agritourism could also have a negative effect on the overall regional image (IP 1). 
Specifically asked about his opinion he stated:

"It [agritourism] has a double-edged effect on the image, which is why I said earlier that you don't necessarily have to link it with agritourism, because from the point of view of economic development, you can also come up with the idea that agritourism is where people wear rubber boots and suchlike." (IP 1)

..."That is a bit rural structured, a bit detached, a bit provincial and so on and that is a mood or an image which we as a business location and as a region do not perceive as positive but on the contrary, we claim that we are an open region which is open to new things and that there is a lot happening here." (IP 1)

In this context, the interview partner favors the music festivals taking place in the Kleve region, which he believes go in a completely different direction of image building than general tourism and especially agritourism.

But he further adds:

"This does not mean that there can be no agritourism - of course that is what we stand for in our region" (IP 1)

This statement of an administration official suggests that agritourism is lacking commitment and is not on the local political agenda. These ambivalent statements are in line with those of a manager of an agribusiness network, stating:

"We have no farms with us now, where agritourism is important." (IP 5)

Continuing:

"It would be desirable for the Lower Rhine district to establish itself as an agritourism region, so to speak, and why not?" (IP 5)

The interview partner believes that by supporting agritourism, regional businesses would gain an economic advantage:

"This means that if you want to promote the region and the companies, you have to find some kind of system where they have a concrete, continuous benefit from it, then there is also a continuous, intensive commitment in this area." (IP 5)

Support by regional politicians could make agritourism an important niche market in tourism and pave the way to future successful regional development:

"If politics says our agritourism is important to us in the region, has a meaning, then first of all, it is a signal that someone has the idea." (IP 5)

Agritourism in Kleve County is not yet fully recognized on the local political agenda and is not receiving sufficient support. The signal is there, but it is not widely heard yet. Two interview partners think this may represent a missed opportunity for regional development as they both state:

"I believe that here in the region, the potential for combining or linking agriculture and tourism is very high and has only been exploited to a small extent so far." (IP 2; IP 5)

These answers show that the number of agritourists is expected to increase with further regional support and commitment by entrepreneurs and politicians:

"People are interested in everything [regarding food production] at the moment, where you can see where products come from. How are they produced? What are the working conditions to produce food? What is the value chain? (IP 2)

"Our main target group...is certainly in the nearby conurbation... for just short vacationers' and weekend stays..." (IP 1)

The interest in agritourism is growing but until now only a few rural entrepreneurs have successfully entered the market. Personal engagement to provide positive experiences and a certain degree of authenticity represented by the 'Landfrauen'-network are seen as important 
success factors for agritourism. At the same time, proximity to conurbations may be a major region-specific success factor for its development. The reported social acceptance of agritourism in the local community is high. A better infrastructure with cooperating beneficial networks would facilitate the spread of information on regional activities and may open new business opportunities. According to the interviews, political support seems to be hesitant and mostly perceived as insufficient. A stronger engagement may be needed to respond to consumer demands and generate more regional economic benefits.

\section{Discussion}

What are the success factors of agritourism?

The growing demand for agritourism mainly stems from people living in urban centers looking for a time-out and leisure in a natural environment (Barbieri \& Mshenga, 2008) Agritourism offers the opportunity to experience nature and learn about animal husbandry, food production, maintenance and sustainability of natural resources. It provides authentic farm life experiences. Families are especially interested in additional activities offering entertainment, e.g., amusement parks or seasonal markets, and education in proximity to their home where they spend a day or a few nights. Friendly interaction with locals, cycling and shopping opportunities for regional foods and vegetables support memorable experiences, which are essential for the development of a successful agricultural holiday destination image.

In 2020, the COVID-2019 pandemic hit and changed global travel behavior. Tourism slowed down or was stopped entirely, long distance destinations were hit the most (WTTC, 2019) and had been replaced by easy to reach domestic-holidays whenever possible at all. Travel restrictions forced the tourist industry to develop new concepts in favor of domestic tourism (UNWTO, 2020b). The UNWTO (United World Travel Organization) experts expect for 2020 an overall decline of tourism of $70 \%$. Most experts expect travelling to pick up again in quarter 3 of $2021,20 \%$ of them expect travelling to resume only in 2022 (UNWTO, 2020a).

Before the pandemic, the tourism industry was already confronted with major challenges regarding environmental protection and carbon emissions. The sudden market changes in the course of the pandemic overlie an emerging trend for the protection of climate and nature. Environmental protection, sustainable tourism and the preservation of the social and cultural heritage is receiving more attention (LaPan \& Barbieri, 2013). This may be a chance for emerging local niche markets like agritourism, offering nearby recreation, education and entertainment. By strengthening their competitive image and responding to consumer demands regional marketing can take advantage of current trends to protect the environment and local culture (Echtner \& Ritchie, 2003; Govers, 2007).

In terms of agritourism, Kleve County is still underdeveloped in comparison to other rural holiday destinations in Europe. How can they attract more tourists and what are the underlying factors for success? The interviews carried out in this paper's case study suggest several possible causes, including an ambivalent local political awareness combined with a missing commitment. The successful development of Italian and Austrian agritourism shows the importance of political commitment. Supporting legislation are cornerstones for regional development for future success. The relevance and economic potential of agritourism has been discussed in numerous studies (Barbieri et al., 2017; Ohe \& Ciani, 2010). Kleve County is supported by European programs that could develop into economic success with stronger political support and commitment. Most experts agree that Kleve County provides ideal conditions in regard to landscape and nature which are a prerequisite for sustainable agritourism. It can create additional income for small and medium-sized farms in need of economic support.

In other words: the interviews suggest that Kleve County possesses abundant opportunities which cannot yet be realized due to general lack of awareness. Agritourism has not reached the political agenda and therefore does not receive sufficient political support (IP 1, 6, 7). Currently, political interest rather favors music festivals for its public image effect (IP 1, 3), which are not related to agritourism but may provide general awareness about the region. 
Proximity to conurbations is valued as a major advantage and success factor for agritourism as was confirmed by the interviewed experts. In line with the current literature, the experts state that good accessibility enables visitors to come for day trips, weekends and short holidays to find leisure and pleasure in a calm environment (IP 4) (Barbieri, 2019).

The decision of tourists to visit a holiday destination is not only a matter of proximity and regional image but is further influenced by seasonal and expected weather conditions (Saito \& Strehlau, 2018). Warmer southern European regions attract higher numbers of visitors than northern European regions in Europe and have longer tourist seasons (Lise \& Tol, 2002). The climate of the Lower Rhine Area allows a tourism season that lasts from spring to autumn. Some tourists visit the region in November or December for wellness and Christmas markets (IP 4).

Popular agritourism regions like South Tyrol and Bavaria agritourism demonstrate that wellestablished networks contribute to economic success by connecting the farms and other local stakeholders. Accompanying government programs can improve local infrastructures and maintain natural and cultural resources (Karampela, Kavroudakis, \& Kizos, 2019). They add to the satisfaction of agritourists by organizing rural events, creating emotions and memories (Zatori et al., 2018). Two private networks ('Agrifun', 'Milchradweg') in Kleve County strive to preserve local authenticity and to increase the regional image. Bicycle routes are leading through the region alongside milk farms that occasionally open their doors for visitors. Historic sites add to the rural experience (Agrifun in the south of Kleve County and Milk Route in the North of Kleve County). Both projects have been initiated by the 'Landfrauen'-network. The experience collected plays a significant role in the image building process and the choice of destination (Echtner \& Ritchie, 1991; Karampela \& Kizos, 2018; Reynolds, 1965). Most interview partners in the case study reported on in this article believe that there are many missed opportunities for the improvement of agritourism through networks and private-public partnerships.

Agritourism mainly depends on private enterprises. Only a few local farm entrepreneurs have recognized the opportunities to extend or transform their farm business by overcoming traditional barriers. They act independently with no or little network support. They have either opened their farms to visitors and offer room and board or have successfully changed their farming business into event locations. These changes do not receive sufficient attention and support yet and may have a limited positive impact on the regional development of agritourism. Building reliable network structures with beneficial relationships could improve agritourism providing future benefits to all participants (Wang \& Fesenmaier, 2007). This could be achieved by incenting and strengthening the existing 'Landfrauen'-network.

In short: Kleve County is still in the infancy of agritourism development, but the interviews and observations we made suggests that the potential for a successful development of this increasing niche in the tourism industry is there.

Attracting more agritourists to the region could diversify the rural economy and help to earn additional financial resources necessary for the preservation and maintenance of the farm lands, ecosystems and historic sites (Karampela et al., 2019) and thus also lead to more sustainable development.

\section{Conclusion}

(1) Based on the case study of agritourism in Kleve County, we argue that successful agritourism in Europe's largely unknown rural areas depends on an organized structure of three main key variables. These success factors are the following: Geographic location and the proximity of agritourism offerings to urban centers.

(2) Political awareness of the significance of agritourism for the economy and the preservation of the environment.

(3) Networks between rural businesses that strengthen regional tourism by offering diverse entertainment programs and learning activities about food production.

These findings are based on the case of Kleve County, but may be useful for other comparable European rural regions which also intend to develop agritourism. Although the case study we 
carried out was limited in scope, we think that Kleve County meets the requirements regarding geographic location but only partially meets them for political awareness and networks. The political focus and the diversity of networks have not yet reached their full potential and, as we see it, should be more developed in the future. A limitation of the case study is the focus on agritourism agents (supply side), omitting the view of agritourists (demand side). This offers a future research possibility to complement the research results.

\section{Academic references}

[1] Barbieri, C. (2019). Agritourism research: a perspective article. Tourism Review, 75(1), 149152. DOI: 10.1108/TR-05-2019-0152.

[2] Barbieri, C., Mahoney, E. \& Butler, L. (2008). Understanding the nature and extent of farm and ranch diversification in North America. Rural Sociology, 73(2), 205-229. DOI: 10.1526/003601108784514543.

[3] Barbieri, C. \& Mshenga, P. (2008). The role of the firm and owner characteristics on the performance of agritourism farms. Sociologia Ruralis, 48(2), 166-183. DOI: 10.1111/j.1467-9523.2008.00450.x.

[4] Barbieri, C., Sotomayor, S. \& Aguilar, F. (2017). Perceived benefits of agricultural lands offering agritourism. Tourism Planning \& Development, 16(1), 43-60. DOI: $10.1080 / 21568316.2017 .1398780$.

[5] Bertacchini, E., Nuccio, M. \& Durio, A. (2019). Proximity tourism and cultural amenities: evidence from a regional museum card. Tourism Economics 27(1), 187-204. DOI: $10.1177 / 1354816619890230$.

[6] Bolton, R. \& Drew, J. (1991). A multistage model of customers' assessments of service quality and value. Journal of Consumer Research, 17(4), 375-384. DOI: 10.1086/208564.

[7] Brunner-Sperdin, A. \& Peters, M. (2009). What influences guests' emotions? The case of high-quality hotels. Journal of Tourism Research, 11(2), 171-183. DOI: 10.1002/jtr.718.

[8] Cohen-Hattab, K. \& Kerber, J. (2004). Literature, cultural identity and the limits of authenticity: a composite approach. International Journal of Tourism Research, 6(2), 57-73. DOI: $10.1002 /$ jtr.470.

[9] Cohen, E. (1979). A phenomology of tourism experiences. Journal of Sociology, 13(2), 179201. DOI: $10.1177 \% 2 F 003803857901300203$.

[10] Cohen, E. (1988). Authenticity and commoditization in tourism. Annals of Tourism Research, 15(3), 371-386. DOI: 10.1016/0160-7383(88)90028-X.

[11] Croes, R. \& Semrad, K. (2018). Destination competitiveness. In Cooper, C., Volo, S., Gartner, W. \& Scott, N., eds., The SAGE Handbook of Tourism Management: Applications of theories and concepts to tourism (pp. 77-90). London: SAGE.

[12] Cronin, J., Brady, M. \& Hult, G. (2000). Assessing the effects of quality, value, and customer satisfaction on consumer behavioral intentions in service environments. Journal of retailing, 76(2), 193-218. DOI: 10.1016/S0022-4359(00)00028-2.

[13] Del Bosque, R., San Martín, H., Collado, J., Del Salmones, M. \& Del Mar, G. (2009). A framework for tourist expectations. International Journal of Culture, Tourism and Hospitality Research, 3(2), 139-147. DOI: 10.1108/17506180910962140.

[14] Di Domenico, M. \& Miller, G. (2012). Farming and tourism enterprise: experiential authenticity in the diversification of independent small-scale family farming. Tourism Management, 33(2), 285-294. DOI: 10.1016/j.tourman.2011.03.007.

[15] Echtner, C. \& Ritchie, J. (1991). The meaning and measurement of destination image. Journal of Tourism Studies, 14(1), 37-48. 
[16] Embacher, H. (1994). Marketing for agri-tourism in Austria: strategy and realisation in a highly developed tourist destination. Journal of Sustainable Tourism, 2(1-2), 61-76. DOI: 10.1080/09669589409510684.

[17] Flanigan, S., Blackstock, K. \& Hunter, C. (2014). Agritourism from the perspective of providers and visitors: a typology-based study. Journal of Tourism Management, 40, 394405. DOI: 10.1016/j.tourman.2013.07.004.

[18] Ghali-Zinoubi, Z. \& Toukabri, M. (2019). The antecedents of the consumer purchase intention: sensitivity to price and involvement in organic product: moderating role of product regional identity. Trends in Food Science \& Technology, 90, 175-179. DOI: 10.1016/j.tifs.2019.02.028.

[19] Gil Arroyo, C., Barbieri, C. \& Rozier-Rich, S. (2013). Defining agritourism: a comparative study of stakeholders' perception in Missouri and North Carolina. Journal of Tourism Management, 37(8), 39-47. DOI: 10.1016/j.tourman.2012.12.007.

[20] Govers, R., Go, F. M. \& Kumar, K. (2007). Promoting tourism destination image. Journal of Travel Research, 46(1), 15-23. DOI: 10.1177/0047287507302374.

[21] Hall, C. \& Page, S. (2006). The Geography of Tourism and Recreation: Evironment, Place and Space ( $3^{\text {rd }}$ ed.). London: Routledge.

[22] Jansen-Verbeke, M. (2008). A geographer's gaze at tourism. Document d'Anàlisi Geogràfica, 52, 15-29.

[23] Karampela, S., Kavroudakis, D. \& Kizos, T. (2019). Agritourism networks: empirical evidence from two case studies in Greece. Current Issues in Tourism, 22(12), 1460-1479. DOI: $10.1080 / 13683500.2017 .1379475$.

[24] Karampela, S. \& Kizos, T. (2018). Agritourism and local development: evidence from two case studies in Greece. International Journal of Tourism Research, 20(5), 566-577. DOI: $10.1002 / j t r .2206$.

[25] Konecnik, M. \& Gartner, W. (2007). Customer-based brand equity for a destination. Annals of Tourism Research, 34(2), 400-421. DOI: 10.1016/j.annals.2006.10.005.

[26] Kovacs, B., Carroll, G. \& Lehman, D. (2014). Authenticity and consumer value ratings: empirical tests from the restaurant domain. Organization Science, 25(2), 458-478. DOI: $10.1287 /$ orsc.2013.0843.

[27] LaPan, C. \& Barbieri, C. (2013). The role of agritourism in heritage preservation. Journal of Tourism 17(8), 666-673. DOI: 10.1080/13683500.2013.849667.

[28] Lise, W. \& Tol, R. (2002). Impact of climate on tourist demand. Springer Nature, 55(429449). DOI: $10.1023 / \mathrm{A}: 1020728021446$.

[29] MacCannell, D. (1973). Staged authenticity: arrangements of social space in tourist settings. American Journal of Sociology, 79(3), 589-603.

[30] Mahaliyanaarachchi, R. (2015). Role of agri tourism as a moderated rural business. Tourism, Leisure and Global Change, 2, 193-204.

[31] McGehee, N. (2007). An agritourism systems model: a Weberian perspective. Journal of Sustainable Tourism, 15(2), 111-124. DOI: 10.2167/jost634.0.

[32] McGehee, N., Kim, K. \& Jennings, G. (2007). Gender motivation for agri-tourism entrepreneurship. Tourims
DOI: $10.1016 /$ j.tourman.2005.12.022

[33] Meraner, M., Heijman, W., Kuhlman, J. \& Finger, R. (2015). Determinants of farm diversification in the Netherlands. Land Use Policy 42, 767-780. DOI: 10.1016/j.landusepol.2014.10.013. 
[34] Morgan, N., Pritchard, A. \& Piggott, R. (2003). Destination branding and the role of the stakeholders: the case of New Zealand. Journal of Vacation Marketing, 9(3), 285-299. DOI: $10.1177 \% 2 F 135676670300900307$.

[35] Novelli, M., Schmitz, B. \& Spencer, T. (2006). Networks, clusters, and innovation in tourism: a UK experience. Journal of Tourism Management, 27(6), 1142-1152. DOI: 10.1016/j.tourman.2005.11.011.

[36] Ohe, Y. \& Ciani, A. (2010). The demand trend of Italian agritourism. Journal of Sustainable Tourism 139, 437-448. DOI: 10.2495/ST100371.

[37] Olsen, M., West, J., Ching, E. (2008). Strategic Managment in the Hopitality Industry (3 ${ }^{\text {rd }}$ ed.). New York: John Wiley \& Sons.

[38] Paasi, A. (2003). Region and place: regional identity in question. Progress in Human Geography, 27(4), 475-485. DOI: 10.1191\%2F0309132503ph439pr.

[39] Philip, S., Hunter, C. \& Blackstock, K. (2010). A typology for defining agritourism. Tourism Management, 31(6), 754-758. DOI: 10.1016/j.tourman.2009.08.001.

[40] Pike, S. (2007). Consumer-based brand equity for destinations. Journal of Travel \& Tourism Marketing, 22(1), 51-61. Doi: 10.1300/J073v22n01_04.

[41] Pine, B. \& Gilmore, J. (1998). Welcome to the experience economy. Harvard Business Review 76(4), 97-105.

[42] Pine, B. \& Gilmore, J. (2000). Satisfaction, sacrifice, surprise: three small steps create one giant leap into the experience economy. Strategy \& Leadership, 28(1), 18-23. DOI: $10.1108 / 10878570010335958$.

[43] Porcaro, P. (2009). Agritourism in Italy. Melbourne: International Specialized Skills Institute.

[44] Reynolds, W. (1965). The role of the consumer in image building. California Management Review, 7(3), 69-76. DOI: 10.2307/41165634.

[45] Rickly, J. (2018). Tourism geographies and the place of authenticity. Tourism Geographies, 20(4), 733-736. DOI: 10.1080/14616688.2018.1477169.

[46] Saito, C. \& Strehlau, V. (2018). Tourist destination choice: a bibliometric study. Review of International Business, 13(1), 17-31. DOI: 10.18568/1980-4865.13117-31.

[47] Santucci, F. (2013). Agritourism for rural development in Italy, evolution, situation and perspectives. British Journal of Economics, Management \& Trade, 3(3), 186-200. DOI: 10.9734/BJEMT/2013/3558.

[48] Savage, A., Barbieri, C., Jakes, S. \& Morais, D. (2018). Success of women in agritourism: she will get what she wants. Raleigh (NC): North Carolina State University.

[49] Sidali, K., Huber, D. \& Schamel, G. (2017). Long-term sustainable development of tourism in South Tyrol: an analysis of tourists' perception. Journal of Sustainability, 9(10), Art. 1791. DOI: $10.3390 /$ su9101791.

[50] Sinabell, F. (2001). Multifunctionality of Austrian agriculture - an economic assessment In Penker, M. \& Pfusterschmid, S., eds., Dokumentation der 11. ÖGA Jahrestagung an der Karl Franzens Universität Graz (pp. 245-252). Vienna: Facultas Verlag.

[51] Stotten, R., Maurer, M., Herrmann, H. \& Schermer, M. (2019). Different forms of accomodation in agritourism: the role of decoupled farmer-based accomodation in the Ötztal Valley (Austria). Sustainability, 11(10), Art. 2841. DOI: 10.3390/su11102841.

[52] Streifeneder, T. (2016). Agriculture first: assessing European policies and scientific typologies to define authentic agritourism and differentiate it from countryside tourism. Tourism Management Perspectives, 20, 251-264. DOI: 10.1016/j.tmp.2016.10.003.

[53] Wang, Y. \& Fesenmaier, D. (2007). Collaborative destination marketing: a case study of Elkhart county, Indiana. Tourism Management, 28(3), 863-875. DOI: 10.1016/j.tourman.2006.02.007. 
[54] Xue, L., Kerstetter, D. \& Hunt, C. (2017). Tourism development and changing rural identity in China. Annals of Tourism Research, 66, 170-182. DOI: 10.1016/j.annals.2017.07.016.

[55] Zatori, A., Smith, M. \& Puczko, L. (2018). Experience-involvement, memorability and authenticity: the service provider's effect on tourist experience. Journal of Tourism Management, 67, 111-126. DOI: 10.1016/j.tourman.2017.12.013.

Other sources

[56] Eurostat (2019). Tourism statistics-characteristics of tourism trips. Retrieved from: https://ec.europa.eu/eurostat/statistics-explained/pdfscache/33345.pdf.

[57] Grass, M. (2019, 12-17-2019). Moyland: 36.508 Besucher kamen. Rheinische Post. Retrieved from https://rp-online.de/nrw/staedte/kleve/bedburg-hau-weihnachtsmarktmoyland-hatte-36508-besucher_aid-47787103.

[58] Hirsch, L. (2020, March 11th, 2020). Travel industry could lose $\$ 24$ billion as coronavirus cripples tourism from outside US. Retrieved from https://www.cnbc.com/2020/03/11/coronavirus-travel-industry-could-lose-24-billion-intourism-from-outside-us.html.

[59] IT.NRW (2019). Bevölkerung in Nordrhein Westfalen. Retrieved from https://www.it.nrw/statistik/eckdaten/bevoelkerung-nach-gemeinden93051\#: :text=Bevölkerung.

[60] Landdata (2020). Aktuelle Agrarsubventionen und wie sie beantragt werden können. Retrieved from https://www.landdata.de/magazin/agrarsubventionen-2020.

[61] NRW, L. (2017). Förderung des ländlichen Raums. Retrieved from https://www.bmel.de/DE/themen/laendliche-regionen/foerderung-des-laendlichenraumes/foerderung-des-laendlichen-raumes_node.html.

[62] Statista (2020). Anzahl der Übernachtungen in Deutschland im Jahr 2016. Retrieved from: https://de.statista.com/statistik/daten/studie/757167/umfrage/uebernachtungen-imagrotourismus-in-deutschland-nach-bundesland/.

[63] UNWTO (2020a). International tourism down 70\% as travel restrictions impact all regions. Retrieved from https://www.unwto.org/taxonomy/term/347.

[64] UNWTO (2020b). New data shows impact of covid-19 on tourism as UNWTO calls for responsible restart of the sector. Retrieved from https://www.unwto.org/news/new-datashows-impact-of-covid-19-on-tourism.

[65] WTTC (2019). Travel \& Tourism: Economic Impact 2019 World Retrieved from Statista.com. 